\title{
THE INNOVATIVE PROBLEM SOLVING STRATEGY AS THE MODEL OF TEACHING PROBLEM SOLVING
}

\author{
Rinie Pratiwi Puspitawati \\ Lecturer at Mathematics and Science Faculty, \\ Surabaya State University, Surabaya, Indonesia \\ ORCID: 0000-0002-8683-858, e-mail: rinepuspitawati10@gmail.com
}

\author{
Lenny Yuanita \\ Chemistry Lecturer at Mathematics and Science Faculty, \\ Surabaya State University, Indonesia \\ ORCID: 0000-0001-6351-3311 \\ Yuni Sri Rahayu \\ Biology Lecturer at Mathematics and Science Faculty, \\ Surabaya State University, Indonesia \\ ORCID: 0000-0002-2977-1162
}

The Innovative Problem Solving Strategy (IPSS) was developed as part of preservice teacher training suggesting a new Teaching and Learning Curriculum (TLC). This research is aimed at analyzing the IPSS effectiveness if applied to solving problems concerned with plant anatomy, as well as at teaching students to use the problem solving strategy in innovative teaching (IT2), and the correlation of innovative ideas and TLC. This article is based on a case study on 94 students of Biology Department in Surabaya State University 2016/2017. The participants were divided into three groups. The data was collected through the assignment of developing a scientific project based on the indicators of innovative study, problem, work step, result, conclusion and developing TLC. The technique of data analysis took into account the indicator proportion, innovation testing and Pearson correlative testing. The results showed that (1) the average of each indicator achievement was $\geq 0,7$, (2) the result obtained for three groups was consistent, and (3) there was a positive correlation between the innovative ideas and Teaching and Learning concept. Thus, IPSS turned out to be efficient for the teacher to apply the innovative ideas and could be used as a role model for being introduced in the curriculum.

Key words: Strategy, Education, Problem Solving, Teachers, Innovative Problem Solving Strategy, Teaching and Learning Concept.

Стратегія інновачійного розв'язання задач була розроблена як частина підготовки майбутніх вчителів, що передбачає розробку нової програми навчання. Це дослідження спрямоване на аналіз ефективності стратегії інноваційного розб'язання задач, якщо Він застосовується $b$ галузі фітотомії, а також для 
навчання студентів розв'язувати задачі застосовувати інновачійний метод. У статті висвітлено дослідження, яке охопило 94 студенти кафедри біологіӥ Державного університету Сурабая у 2016-2017 навчальному році. УчасникіВ були розподілено на три групи. Статистичні дані були зібрані шляхом Виконання студентами наукового проекту та використання інфдикаторів інноваційного дослідження, розробки плану роботи, обробки результатів, написання Висновків. Методика аналізу даних враховувала пропориію показникіВ, тестування інновачій та корелячійне тестування Пірсона. Результати показали, що середня Величина кожного індикатора була $\geq 0,7 ;$ результаті, отримані для тръох груп, стали закономірними, оскільки прослідковувалася позитивна кореляція між інноваційними ідеями та концепџією навчання. Таким чином, стратегія інноваційного розб'язання задач Виявився ефрективною при застосуванні інновачійних ідей майбутніми вчителями $i$ може бути Використанана як рольова модель, яку потрібно застосовувати в прочесі навчання.

Ключові слова: стратегія, освіта, розб'язання задач, майбутні вчителі, інновачійна стратегія розб'язання задач, концепиія Викладання та навчання.

\section{Introduction}

The Indonesian government has applied regulation to standardize the quality of graduates at different education levels. Graduates are required to own competence of logical, critical, systematical and innovative thought as mentioned in the regulation of Ministry of Research, Technology and Higher Education No. 44 on the National Standard of Higher Education. As stated in Indonesia National Quality Regulation students are supposed to have understanding of problem solving.

Problem solving competence must contribute to the ability of creative, productive, critical, individual, collaborative and communicative thought and action (Department of Education and Culture, 2016 No. 20).

Teachers also demand that students should own problem solving competence. It is necessary that the students' problem solving skills should become a model of how they implement it.

Some related studies show that relevant methodology is obtained after constant training (Anwar, et al., 2012; Meschede, et al., 2017; Pangestika and Alfarisa, 2015). Other studies also show that $e$-supervision is effective to design teachers' cognitive training, learning guides, and new teacher's reflection (Alger 2009; Aziz, 2014). In addition, some research shows that there is a positive correlation between the visions of professional teachers, knowledge and skills of science teachers (Suh \& Park, 2017). The previous research analysis shows that the competence of methodology training is separated from material competence.

Methodology is targeted on the innovative learning process and 21st century skills with the focus on problem solving and critical thinking (Živkovic, 2016). Other researchers prove that the ability to master problem solving is obtained if it is learned with the material content (Green \& Ruggiero, 2007). The material concerning problem solving may be possible to train teachers' skills, to construct the knowledge and to link it to the previous experience (Sitti, 2013).

There are various studies related to problem solving. They concern the steps of learning process concerning problem solving: (1) analyzing and identifying data, (2) stating the problem concerning material content, (3) finding alternative problem solutions, (4) solving the problem, and (5) evaluating and verifying the result (D'Zurilla, \& Goldfried, 1991; Ersoy, 2014). The learning is limited only to training problem solving skill. Another effect needed is to obtain new ideas to design materials. The learning process is a form of the model to create those new ideas. This study develops the specific strategy to implement problem 
solving in the learning process in order to know how to teach the students about problem solving. The strategy is taught to give evaluation and appreciation of the steps of solving problem.

Schmidt, et al., (2011) argue that evaluating and appreciating are done to obtain teachers' skills on solving problem and their understanding about the steps of solving problem. The learning process can be tested on different topics in order to strengthen the effect. That learning process may give experience about inquiry process as a way of learning and cognitive constructive approach.

The steps developed in this study are based on relevant theoretical base and philosophical view of problem solving and are data-based which facilitates problem solving achievement and creates innovative ideas for curriculum design.

Problem solving is applied in technical cases related to material content. Appreciative inquiry is applied in the complex of social problems or building social condition to create creativity of problem solving (Holmberg, 2009 in Hansen, 2012). This case is strengthened by the research result of Boser (1993) and Willis (2015) who recommend instructional activity to improve the quality teachers' problem solving.

The analysis result of Sweitzer and Ronald (1983) show that the procedure of teachers' effective preparation, include: (a) systematical observation during teaching practice, (b) micro-teaching, and (c) feedback. Fernandes (1988) concludes that teachers must be competent in problem solving. Wright (1990) and Boser's research (1993) explain that mbeing able to solve the problem does not mean being successful in teaching problem solving. Teachers should be taught the methodology of problem solving which is gained through practical activities and theoretical knowledge. The constructivist shift in pre-service training will result in increasing the teachers' competence.

This study presents teachers' Innovative Problem Solving Strategy of (IPSS) in order to improve both: future teachers' problem solving skills in pre-service training and the teachers' effectiveness in the classroom after they have started their career. Each problem can be solved with different responses. The steps of problem solving chosen in this study are those presented by D'Zurilla \& Goldfried (1991) and Ersoy (2014). Also, there are two additional steps, namely: (6) improving innovative ideas and (7) implementing innovative ideas. The influential steps of the learning process are problem solving itself and positive problem solving view.

The problem solving view emphasizes identifying problem, analyzing problem causes, responding to the problem and solving it. This step is applied in the technical problems. Meanwhile, the positive problem solving view stresses on the cognitive activity of identifying the success and strength, identifying factors that influence the result, predicting an achievement and innovating the best work. That view becomes the basic of learning appreciative inquiry (AI) which facilitates innovative ideas through appreciative skills (Henderson, et al. 2011; Tosati, et al., 2015). It is also relevant to be implemented in complex social problems (Holmberg, 2009 in Hansen, 2012). This case is different from learning problem solving which is signed by repetition concept rather than the new concept (Yew and Schmidt, 2008).

The effort of combining problem solving approach and positive problem solving is made to create an approach called as appreciative problem solving (Hansen, 2012). Appreciative problem solving is an approach to find the best things, to analyze the problem and to create innovation. This approach can be implemented to technical problems and complex social condition problems (Holmberg, 2009 in Hansen, 2012).

The implementation of the approach may cause students to appreciate the learning process followed. The innovative strategy of problem solving is taught in plants anatomy to future teachers who, in their turn, may use the advantage of IPSS in class to generate 
innovative ideas about plant anatomy. The innovative strategies related to plant anatomy are expectedto inspire new innovative ideas on TLC and Innovative lessons. The result of this study is measured by the resulting problem solving skill in plants anatomy class and the study plan design (TLC) on innovative class.

The purpose of this study is to check the effectiveness of Innovative Problem Solving Strategy in its classroom application. This effectiveness is based on (1) final indicator of problem solving skill, (2) final indicator of study plan design, and (3) the correlation between the appreciation of plants anatomy class and the curriculum designed for Innovative class (IC).

\section{Methodology}

This study used Pre-Experimental Design of a case study. The participants of this study were 96 students of Biology Education at State University of Surabaya (UNESA) 20132014. The students were divided into three groups (A, B, and C) based on their class. Each class had a different number of students $-36,43$ and 17 . The study was conducted on even semester 2016/2017 during 9 weeks. The classes were held from February to June 2016. The IPSS implementation in class was supported by such teaching materials as student activity guides, lecture course units, assessment sheets of plant anatomy project reports, and theoretically valid TLC assessment sheets.

The independent variable in this research was IPSS. Response variables in this research were: (1) the completeness of problem solving skill indicator, (2) the completeness of TLC formulation, (3) correlation between the ability to appreciate plant anatomy and the TLC developed in innovative learning course (ILC).

The indicators of problem solving skills measured in this study included: (1) formulating the idea of problem-solving topics, (2) formulating problems, (3) formulating hypotheses, (4) identifying variables, (5) defining variables, (6) solving problems, (7) explaining the causal relationships between variables, (8) formulating conclusions, (9) evaluating the implementation, (10) identifying the stages of the problemsolving process, (11) identifying the advantages of the problem-solving stages (Airey \& Linder, 2009).The achievement of the indicator was measured by the project report of plant anatomy. These indicators were covering a series of aspects, including the formulation signs of the national TLC (regulation of Education and Culture ministry, No. 22, 2016) and the principle of instructional design. The correlated aspect was the appreciating skill produced in the Plant Anatomy lectures with the aspects of TLC produced in the ILC.

Data analysis started with a different test of Anova or Kruskal-Wallis (Trihendradi, 2012). This test was done with IBM SPSS 16.0 software to see the differences in the three student groups' results. The next step was a quantitative descriptive analysis by calculating the proportion of learning indicator achievement. The criteria of completeness were achievement of the proportion of indicators, at least 0.7. Classic completeness was based on the percentage of achievement of learning outcomes $\geq 70$ set, at least $70 \%$ of the number of students.

\section{Results and Discussion}

\subsection{Results}

\subsubsection{Problem Solving Skill}

The implementation of IPSS was carried out on the topic of stems, roots, and leaves. A single plant anatomy report was produced in each topic. In addition, the reports were assessed based on valid assessment criteria. Meanwhile, the results were assessed in the range $0-100$. Data obtained was in the form of learning values toward problem solving skills.

The problem solving skill of 3 groups resulted in normal and homogeneous distribution values. Thus, Anova test wascontinued. Anova test results P-value $0.082 \geq \mathrm{a}$ (0.05), therefore the value of learning outcomes among the 3 groups was not significantly 
different.

The problem solving learning skill result was analyzed by a quantitative descriptive method which obtained $84.55 \%$ percentage from 3 groups, the details of the results for each group are presented in Figure 1.

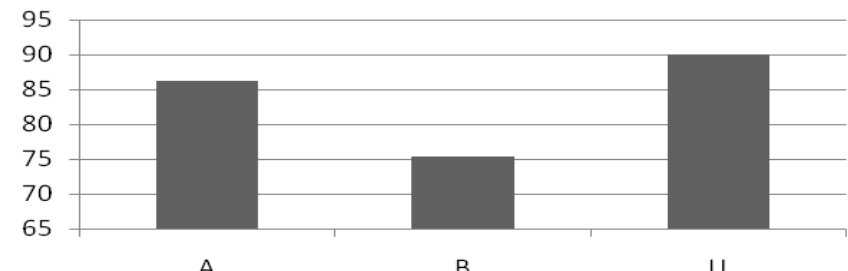

Figure 1. The percentage of students who demonstrated a problem solving skill.

The achievement of the proportion in each indicator of problem solving was above 0.7 . The achievement of indicators is displayed in figure 2.

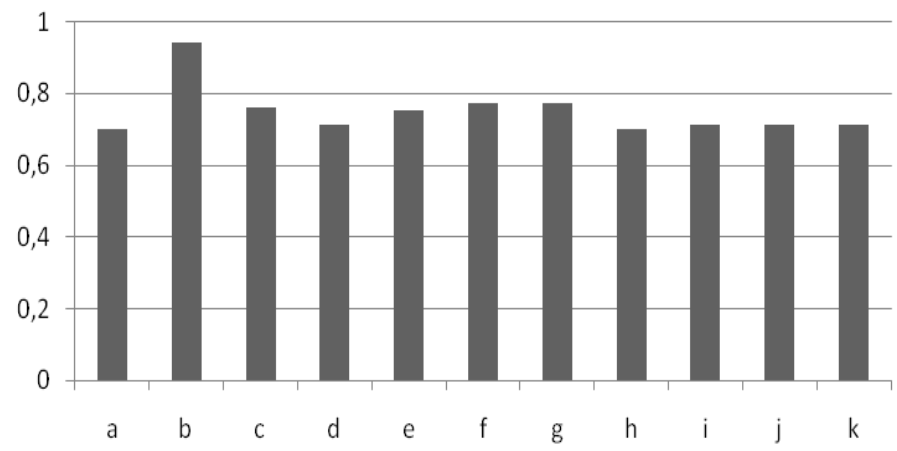

Figure 2.The achievement of problem solving proportion

Note:

a. Stating the main topic of solving problem.

b. Formulating problem.

c. Formulating hypothesis

d. Identifying variables

e. Defining variables

f. Designing problem solving

g. Explaining the relation between causal effect and variable

h. Formulating the conclusion

i. Evaluating the activity

j. Identifying the process of solving problem

$\mathrm{k}$. Identifying the advantages of problem solving process

\subsubsection{Curriculum Design}

The result of curriculum design showed that the participant had normal and homogenous distribution thus the Anova test was continued. The result obtained P-value $0.115 \geq a(0.05)$ so that the score of the participants were quite same. 
The result of curriculum design was analyzed descriptively and qualitatively obtained $76.15 \%$ of students who completed the proportion. The detail is displayed in figure 3 below.

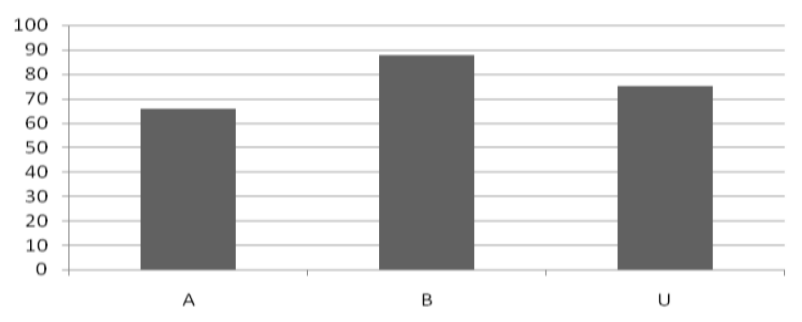

Figure 3. The percentage of total students completing the learning result of preparing the lesson plan.

The completeness of indicator proportion was about 0.91 . The detail information is displayed in the table below.

Table 1. The Achievement of TLC Indicator Proportion

\begin{tabular}{|c|c|c|}
\hline Aspect & Aspect Indicator & Proportion \\
\hline \multirow{4}{*}{$\begin{array}{l}\text { Indicator } \\
\text { explanation }\end{array}$} & Relevant indicator to basic competence (KD) & 0.91 \\
\hline & $\begin{array}{l}\text { The amount of indicator that might achieve teaching- } \\
\text { learning concept (TLC) }\end{array}$ & 0.93 \\
\hline & Proper writing of the indicator & 0.93 \\
\hline & Measured operational work & 0.93 \\
\hline \multirow[t]{5}{*}{ Material } & Relevant material to KD from K13 to K14 & 0.84 \\
\hline & $\begin{array}{l}\text { The material concept was clearly explained in the } \\
\text { curriculum }\end{array}$ & 0.57 \\
\hline & The systematical concept of presentation & 0.63 \\
\hline & $\begin{array}{l}\text { Relevant and real phenomena had to be added to the } \\
\text { material }\end{array}$ & 0.31 \\
\hline & $\begin{array}{l}\text { The topic chosen might create problems that implement } \\
\text { fundamental concepts }\end{array}$ & 0.55 \\
\hline \multirow{7}{*}{$\begin{array}{l}\text { Learning } \\
\text { process }\end{array}$} & Facilitating students with phenomena & 0.93 \\
\hline & $\begin{array}{l}\text { Teachers had to have the plan to facilitate students new } \\
\text { phenomena thus they were able to analyze the problem }\end{array}$ & 0.98 \\
\hline & facility plan to state problem & 0.96 \\
\hline & plan for student to design problem solving & 0.76 \\
\hline & plan to facilitate the design in order to solve the problem & 0.98 \\
\hline & Prepare students' guide & 0.76 \\
\hline & the example of project report & 0.31 \\
\hline \multirow[t]{4}{*}{ Scoring } & preparing to score attitude and technique of observation & 0.94 \\
\hline & scoring the project related to cognition and skill & 0.92 \\
\hline & rubric for the scoring project & 0.75 \\
\hline & $\begin{array}{l}\text { the rubric score included preparation, plans, activity and } \\
\text { conclusion }\end{array}$ & 0.68 \\
\hline
\end{tabular}

\subsubsection{The Correlation between Appreciation Ability and Curriculum}

The analysis of correlation was done to test the relation between appreciation ability and curriculum designed in ILC. The indicator correlated as explained in table 2 while the result of testing the correlation is displayed in table 3. 


\begin{tabular}{|c|c|}
\hline $\begin{array}{l}\text { Indicator of appreciation ability } \\
\text { in plants anatomy class }\end{array}$ & Indicator in Curriculum \\
\hline $\begin{array}{l}\text { Ideas } \\
\text { Reflection } \\
\text { Identifying process of problem } \\
\text { solving } \\
\text { Identifying the advantages of } \\
\text { solving problem process }\end{array}$ & $\begin{array}{l}\text { Determining the relevant phenomena } \\
\text { The chosen topic might stimulate problem } \\
\text { appearance } \\
\text { Facilitating students with phenomena } \\
\text { The phenomena were written in the study plan } \\
\text { Teachers' plan concerning students' facilities to } \\
\text { identify facts and create problem } \\
\text { Facility of stating problem } \\
\text { Plans about students' activity to design problem } \\
\text { solving } \\
\text { Plans for work performance format } \\
\text { Report project example systematically }\end{array}$ \\
\hline
\end{tabular}

Table 3. The conclusion of correlation testing of appreciation ability and Study Plan Design

\begin{tabular}{|c|c|c|c|c|c|}
\hline Class & Data Source & $\begin{array}{l}\text { P-value } \\
\text { (sig) }\end{array}$ & $\alpha$ & Conclusion & $\begin{array}{l}\text { Co- } \\
\text { efficient } \\
\text { correlation }\end{array}$ \\
\hline \multirow[t]{2}{*}{ A } & $\begin{array}{l}\text { The ability of appreciating } \\
\text { plants anatomy class }\end{array}$ & \multirow[t]{2}{*}{0.000} & \multirow[t]{2}{*}{0.05} & \multirow[t]{2}{*}{ Ho rejected } & \multirow[t]{2}{*}{0.903} \\
\hline & Study plan & & & & \\
\hline \multirow[t]{2}{*}{ B } & $\begin{array}{l}\text { The ability of appreciating } \\
\text { plants anatomy class }\end{array}$ & \multirow[t]{2}{*}{0.001} & \multirow[t]{2}{*}{0.05} & \multirow[t]{2}{*}{ Ho rejected } & \multirow[t]{2}{*}{0.729} \\
\hline & Study plan & & & & \\
\hline \multirow[t]{2}{*}{$\mathrm{U}$} & $\begin{array}{l}\text { The ability of appreciating } \\
\text { plants anatomy class }\end{array}$ & \multirow[t]{2}{*}{0.000} & \multirow[t]{2}{*}{0.05} & \multirow[t]{2}{*}{ Ho rejected } & \multirow[t]{2}{*}{0.563} \\
\hline & Study plan & & & & \\
\hline
\end{tabular}

The result of the analysis showed that the ability to appreciate had a positive correlation with curriculum design.

\subsection{Discussion}

The IPSS is implemented effectively to achieve problem solving indicators and develop TLC. The number of students who completed the proportion was between $75 \%$ $91 \%$, with an average of $84.55 \%$ (Figure 1 ). The number of students who completed the TLC varied between $67 \%-89 \%$, with an average of $76.15 \%$ (Figure 3 ). The data shows that the minimum learning completeness criteria achieved, i.e. $\geq 70 \%$ of students who achieved learning outcomes is $\geq 70$.

The Performance completion concerning the problem solving indicator reached $100 \%$ with 0.7-0.93 distribution. The number of complete RPP indicators reached $75 \%$, with 0.31 0.98 of proportion. The data also shows the minimum learning completeness criteria has been achieved. The analysis of correlation test data between the ability to appreciate the class of Plant Anatomy with the TLC showed a positive result.

The overall results obtained give positive results on the measured result variable that 
indicate IPSS effectiveness for achieving the three categories of learning outcomes in this study. The three variables that become indicators of this research are (1) achievement of problem solving skill indicator, (2) achievement of TLC formulation, (3) correlation between the ability to appreciate plants anatomy class and TLC developed on innovative learning course (ILC).

IPSS is specially designed to have a bridging stage of structured problem solving skills; it trains problem solving skills in each phase. In cycle 1, the problem solving skills are systematically trained starting from formulating the problem, formulating the hypothesis, identifying the experimental variable, defining the operational definition of the experimental variables, designing and executing the experimental procedures, charting, analyzing the data, formulating the conclusions and formulating implementing innovative ideas. These problem-solving skills activities are relevant to Dogan \& Kunt (2016) research results, Zeidan \& Jayosi (2015), who concluded that problem-solving skills are procedural, experimental, and systematical scientific investigation skills as the basis of scientific literacy.

The material review in IPSS employs real issues related to plant anatomy. This is reinforced by the notion that problem-solving skills are strongly related to material content (Hoskinson, et al., 2013). The problems were extracted from the results of research related to plant anatomy published in various articles. The dynamics of associative thinking, making comparisons and evaluating are always done during the lecture process through the presentation of anatomical plant phenomena associated with authentic problem solving. The phenomenon presented plays an example that can be appreciated to produce innovative ideas. (Holmberg, 2009 as cited in Hansen, 2012).

The implementation of problem solving skills is done in cycle 2 . The activity starts from the direct exploration of concepts and facts, known as enactive learning (Moreno, R., 2010). Subsequent activities are formulating problems, hypotheses, identifying experimental variables, defining operational definitions of experimental variables, designing and carrying out experimental procedures, performing observations, drawing, analyzing data, and formulating conclusions.

The learning process begins through the rich authentic tasks associated with the study of the case (Funke \& Frensch, 2007). These learning steps can lead students to appreciating the learning process experienced to find problems and to think about the solution as well as bring up innovative ideas. The process occurs is the cognitive process of the brain to find a solution (Wang \& Chiew, 2010).

The achievement of the problem-solving skills is recommended from Tarhan (2013), and Magdalena, et al (2014) study. The implementation of IPSS allows repetition to practice problem solving skills and to examine concepts. The second cycle of learning enables students to study the "proximal development zone", and the scaffolding of the first cycle (Amri, 2013: Slavin, 2011). It is similar to those of Laal \& Ghodsi (2012), Burns, Pierson, \& Reddy (2014), DeWitt \& Alias (2014) who improved learning outcomes after repetition of strategies for different topics. This becomes a positive transfer process of learning and skills in formulating innovative ideas and problem-solving skills.

Continuing learning experiences allow cognitive structure and self-regulated apprenticeship processes (Slavin, 2006). The modeling principles through examples of plant anatomy problem studies are structured modeling, allowed cognition, affective and behavioral changes as a result of observing behavior (Moreno, 2010). It can improve memory through the activity of assessing knowledge to gain knowledge retention (Destalia, et al., 2014). Other research studies show that problem solving has successfully fostered students' problem-solving thinking skills in various academic fields (Thabet, 2017; Major \& Palmer, 2001).

Detail proportion achievement of each aspect in the RPP assessment is shown in Table 
1. The difficulty of selecting topics and phenomena to raise the problem is evident from the low proportion of achievement of 0.57 . It shows that students were able to present real phenomena related to the concept of taught. The selection and presentation of phenomena are relevant to problem-based and project-based learning that emphasizes authentic issues (Mayer, 2008).

The plans of learning management steps to teach problem solving skills of proportion achievement are quite high and exceed the minimum criterion of completeness criteria. The data can be an indicator that the student was able to design curriculum to develop problem solving skills.

The assessment indicator to assess the problem solving activities designed by the students was achieved with a proportion of 0.92 . The proportion of completeness rubric on the assessment reached 0.75. Overall, it can be said that TLC indicators can be achieved beyond the minimum criteria.

The competencies of TLC are related to the ability to appreciate and to train innovative ideas through the course of Plant Anatomy which is significantly and positively correlated (Table 3). The correlation builds up the ability to appreciate innovative ideas in Plant Anatomy with some indicators to design TLC.

The correlation is possible since $90.91 \%$ of students understood the lectures followed in Plant Anatomy as the work process of problem solving, discussing and presenting. Among the students, 39.39\% of students were able to give feedback of the lecture, which consisted of problem formulation, problem solving design, data collection, the results conclusion and presentation. It was considered as a new lecture strategy by $87.87 \%$ of students.

The data can be interpreted that the ability of reflection and appreciation can influence the innovative idea. Referring to the modeling theory by Bandura, there can be cognitive, affective and behavioral changes as the result of the observation and extraction process with other behaviors and explanations (Moreno, 2010). Students can learn through observations and explanations from others. Students should pay attention to the model of the learning process. In order for the existing procedural knowledge to be remembered, the student must do the repetition and re-produce it (Moreno, 2010). This is evident from the repetitive learning experience of IPSS in Plants Anatomy class and the Innovative Learning Course.

The correlation is reinforced by the results of the Moreno (2010) study, stating that positive learning outcomes can be obtained from a modeling. This is reinforced by the fact that the results of student responses related to the topic of the problem posed as a reflection of innovative ideas. Furthermore, $11 \%$ of students studied the association of anatomical structure with environmental conditions in cycle I, thus the topic of the proposed problem was also related to anatomical structure with environmental conditions (17\%). The largest percentage of $89 \%$ of students in cycle I studied the concept of plant anatomy structure, so they considered the problems proposed in cycle II was related to the concept of plant anatomy structure $(82 \%)$.

The acquisition of the data reinforces the result that applying IPSS is effective to provide inspiration to bring up innovative ideas of learning management. An inspiring experience is a lecture process conducted on anatomy of plants, while the innovative idea is one of the products in the Innovative Learning Course. Creative thinking as the basis for generating this idea must be through preparatory steps, incubation, insight, evaluation and elaboration.

\section{Conclusion}

Innovative problem solving strategy (IPSS) is effective for teacher learning outcomes with the following results: (1). Completion of problem solving skills indicator reached 100\% with $0.70-0.93$ distributed proportion. The number of students who fully mastered problem 
solving skills reached $84.55 \%$. (2) The completeness of the RPP indicator reached $75 \%$ with 0.31-0.98 distributed proportion. The number of students who completed mastering the preparation of RPP reached $76.15 \%$. There is a positive correlation between the ability to appreciate Plants Anatomy class and TLC developed in the Innovative Learning Course.

\section{References:}

Airey, J., \& Linder, C. (2009). A Disciplinary Discourse Perspective on University Science Learning: Achieving Fluency In a Critical Constellation of Modes. Journal of Research in Science Teaching, Volume 46 (1), pp.27-49.

Alberts, B. (2009). Making a Science of Education Science 323 (15). Available at: http://science.sciencemag.org. [Accessed 6 January 2015].

Alberts, B. (2009). Restoring Science to Science Education.Issues Sci. Tech 77-84. Available at: http://science.sciencemag.org. [Accessed 6 January 2015]

Alger, C., E Kopcha, T. J. (2009). E-Supervision: A technology framework for the $21^{\text {st }}$ century field experience in teacher education. Issues in Teacher Education Volume 18 (2), pp.31-6.

Amri, S., E Ahmadi, K. (2010). Proses Pembelajaran Kreatifdan Inovatif dalam kelas. Jakarta: PT. Prestasi

Pusta karya.

Anwar, Y., Rustaan, Y.N., EWidodo, A.(2012). Kemampuan Subject Specific Pedagogi Calon Guru

BiologiPeserta Program Pendidikan Profesional Guru (PPG) yang Berlatar Belakang Basic SainsPradan

Post Workshop. Science Education Journal, Volume 1 (2), pp.157-162.

Aziz, M. S. A. (2014). E-supervision using blog: The graduate students' reaction. Proceedia - Social and

Behavioral Sciences, Volume 118, 322 - 329.

Bao, L., et al. (2009). Learning and Scientific Reasoning Science, Volume 323 (5914), pp.586-587.

Boser, R. A. (1993). The Development of Problem Solving Capabilities in Pre-service Technology Teacher

Education. Journal of Technology Education, Volume 4 (2), pp.11-12.

Brickman, P., et al. (2009). Effects of Inquiry-Based Learning on Student's Science Literacy Skills and Confidence.International Journal for the Scholarship of Teaching and Learning. Volume 3 (2). Available at: http://lrc.quangbinhuni.edu.

Burns, M., Pierson, E., E Reddy, S. (2014). Working together: How teachers teach and students learn in collaborative learning environments. International Journal of Instruction. Volume 7 (1), pp. 17-32.

Destalia, L. S.EApriliya, S. (2014). Peningkatan hasil belajar dan keterampilan pemecahan masalah melalui penerapan pembelajaran berbasis masalah (PBM) dengan metode eksperimen pada materi pencemaran lingkungan. Pancara Journal, Volume 3(4), pp.213-224.

Dewitt, D., Siraj, S., E Alias, N. (2014). Collaborative learning: A module for learning secondary school science. Educational Technology \& Society, Volume 17(1), pp. 89-101.

Dogan, I.,EKunt, H. (2016).Determination of prospective preschool teachers' science process skills. Journal of European Education. Volume 6(1), pp. 32-42.

D'Zurilla, T.J. EGoldfried, M.R. (1991). Problem Solving and Behavior Modification. Journal of Abnormal Psychology. Volume 78(1), pp. 107-126. Available at: http://psycnet.apa.org. [Accessed: 30 December 2012].

Funke,J., EFrensch, P.A. (2007).Complex Problem solving: The European Perspective-10 Years After, in D, $H$, Jonassen (ed), learning to solve complex scientific problem, New York: Lawrence Arlbarum.

Gilles,R. C.N., et al. (2011). Problem-solving consultation: Aplication in evidence-based prevention and intervention. In M.A. Bray \& T.F. Kehle (Eds.) The oxford handbook of School Pshycology. New York: Oxford Press.

Green, L., E Ruggiero, D. (2007). Problem Solving through Digital Game Design: A Quantitative Content Analysis. Computers in Human Behavior. Volume 73(1), pp. 28-37.

Hambach, J., Diezemann, C., E Tisch, M. (2016). Assessment of students' learn competencies with the help of behavior video analysis-are good students better problem solver? Procedia CIRP. Volume 55(1), pp. 230235.

Hansen, D. (2012). Appreciative Problem Solving. Binder paper Submissions Word Appreciative Inquiry Conference May 2012. Ghent-Belgium: Word Appreciative Inquiry Conference.

Henderson, M., et al. (2011). Positive Problem-Solving: How Appreciative Inquiry Works. Strategies and Solutions for Local Government Managers. Volume 43 (3).

Hoskinson, A.M., Caballero, M.D.,EKnight, J.K. (2013). How Can We Improve Problem Solving in Undergraduate Biology? Applying Lessons from 30 Years of Physics Education Research. CBE Life Sci Educ. Volume 12(2). pp. 153-161. 
Indonesia President. (2012). Indonesia President Regulation No 8 of 2012 about framework of Indonesia national qualification. Jakarta: deputy of people's welfare.

Indrawati., N. H. (2016). Pengaruh Penerapan Model Inkuiri Terbimbing Pada Pembelajaran Sub konsep Perubahan Lingkungan Terhadap Hasil Belajar Dan Keterampilan Berpikir Kritis Siswa Kelas X SMA Negeri 6 Banjarmasin. JurnalWahana Bio.Volume 16(1). pp. 1-11.

Magdalena, O., Mulyani, S., ESusanty, E. (2014). Pengaruh Pembelajaran Model Problem Based Learning Dan Inquiry Terhadap Prestasi Belajar Siswa Ditinjau Dari Kreativitas Verbal Pada Materi Hukum Dar Kimia Kelas X Sman 1 Boyolali Tahun Pelajaran 2013/2014. Chemistry Education Journal. Volume 3(4). pp. 162-169.

Major, C, H.,E Palmer, B. (2001). Assessing the effectiveness of problem-based Learning in Higher Education:lesson from the literature. Academic Exchange Quarterly. Volume 5(10). pp. 4-9.

Mayer, R.E. (1992). Guiding Students Cognitive of Scientific Information Text. Journal of Education Psychology. Volume 884 (1). 405-412.

Meschede, N., et al. (2017). Teachers' Professional vision, pedagogical content knowledge and beliefs: On its relation and differences between pre-service and in-service teachers. Teaching and Teacher Education. Volume 21 (7). $p p \cdot 1090-1100$.

Moreno, R. (2010). Educational Psychology. New York: John Wiley \& Sons, Inc.

OECD. Education at a Glance 2012. OECD Indicators. OECD Publishing. Available at: http://dx.doi.org/10.1787/eag-2012-en. 2012.

Pangestika, R., E Alfarisa,A. (2015). Teacher professional education: Strategy of Teacher Professional development and improvement of education quality of Indonesia. Paper at National colloquium at State University of Yogyakarta.

Paul, R. E Elder, L. (2007). The Thinker's Guide: A Glossary of Critical Thinking Terms and Concepts, The Foundation for Critical Thinking. Available at: http://www.criticalthinking.org.

Risriasari, T., Priyono, B., ESukaesih, S. (2012). Model Pembelajaran Problem Solving Dengan Mind Mapping Terhadap Kemampuan Berpikir Kritis Siswa. Unnes.J.Biol.Education. Volume 1(3), pp. 34-41.

Schmidt, H.G.,et al. (2011). The Process of Problem-Based Learning: What Works and Why. Medical Education. Volume 45(1). pp.792-806.

Sitti, S., Sopeerak, S., E Sompong, N. (2013). Development of Instructional Model Based on Connectivism Learning Theory to Enhance Problem-Solving Skill in ICT for Daily Life of Higher Education Students. Procedia - Social and Behavioral Sciences. Volume 103(1). pp.315-322.

Slavin, E. R. (2011). Educational psychology: Theory and Practice. Boston: Pearson.

Suh, K.J., E Park, S. (2017). Exploring the relationship between pedagogical content knowledge (PCK) and sustainability of an innovative science teaching approach. Teaching and Teacher Education. Volume 6(4). Pp. 246-259.

Sweitzer, G.L., \& Ronald, D.A. A. (1983). Meta-Analysis of Research on Science Teacher Education Practices Associated With Inquiry Strategy. Journal of Research in Science Teaching. Volume 20(5). pp.453-466.

Tarhan, L., EAcar-Sesen, B. (2013). Problem Based Learning in Acids and bases: Learning Achievements and Students' Beliefs. Journal of Baltic Science Education. Volume 12 (5). pp.565-578.

Thabet, M., et al. (2017). The Effect of Problem-Base Learning on Nursing Students' decision making skills and Styles. Journal of Nursing Education and Practice. Volume 7 (6). pp.108-116.

Wang, Y., EChiew, V. (2010). On the cognitive process of human problem solving. Cognitive Systems Research. Volume 11(1). pp. 81-92.

Wharton, R., EParry, L. (2003). The good, the bad, and the ugly: using experiential learning in the classroom. The Journal of Scholarship of Teaching and Learning, Volume 3(3), pp.56-68.

Willis, P. (2015). Review from humble inquiry to humble intelligence: Confronting wicked problems and augmenting public relations. Public Relations Review.

Yew, E.H.J. E Schmidt, H. G. (2008). Evidence for Constructive, Self-Regulatory, and Collaborative Processes in Problem-Based learning. Advances in Health Sciences Education, Volume 14(2), pp. 251-273.

Živkovic, S. (2016). A model of critical thinking as an important attribute for success in the 21st century. Procedia - social and behavioral sciences, Volume 232(1), pp.102-108 